\title{
Influence of Climate Variables on the Leaf Morphology of Ebony (Diospyros celebica) and Their Classification Using the Random Forest Algorithm
}

\section{Dani Rofianto}

IPB University: Institut Pertanian Bogor https://orcid.org/0000-0002-6594-7671

Iskandar Zulkarnaen Siregar ( $\nabla$ siregar@apps.ipb.ac.id )

IPB University: Institut Pertanian Bogor https://orcid.org/0000-0002-5419-482X

Yeni Herdiyeni

IPB University: Institut Pertanian Bogor https://orcid.org/0000-0002-3389-1730

\section{Research}

Keywords: Diospyros celebica, leaf morphology, climate, identification, random forest

Posted Date: May 26th, 2021

DOl: https://doi.org/10.21203/rs.3.rs-550356/v1

License: (c) (1) This work is licensed under a Creative Commons Attribution 4.0 International License.

Read Full License 


\section{Influence of Climate Variables on the Leaf Morphology of Ebony (Diospyros celebica) and Their Classification Using the Random Forest Algorithm}

Dani Rofianto ${ }^{1}$, Yeni Herdiyeni ${ }^{2}$ and Iskandar Z Siregar ${ }^{3^{*}}$

\author{
*Correspondence: \\ siregar@apps.ipb.ac.id \\ ${ }^{3}$ Department of \\ Silviculture, Faculty \\ of Forestry and \\ Environment, IPB \\ University, Bogor, \\ Indonesia
}

\begin{abstract}
Background: Climate plays an important role in the growth process of various plant species, and the ebony species is no exception to this. Ebony (Diospyros celebica Bakh.) is a Sulawesi endemic flora species whose wood is widely used as a material for light to heavy construction and important raw material for Indonesia's timber industry. Massive forest exploitation threatens preservation of the Diospyros celebica, so conservation is needed to save it from extinction. However, the difficulty in distinguishing Diospyros celebica in the tillering phase caused many seed collection errors, so a system was needed to identify plants correctly. This study aims to extract leaf morphological features, analyze the correlation between leaf morphological features and climate variables, and classify them based on the region where Diospyros celebica grows.
\end{abstract}

Result: The results show that several leaf morphological characteristics were sufficiently correlated with climate variables such as MAT and MAP. In dry weather, the leaves of Diospyros celebica tend to have relatively small leaf sizes, whereas, in wetter weather, the leaves tend to have a much larger size. The classification results could distinguish leaf morphology based on growing regions with an accuracy rate of $94.59 \%$.

Conclusions: By obtaining a high level of classification accuracy, it can be interpreted that the size of the leaf morphology of the same species (Diospyros celebica) is different in each region, influenced by climate variables, in this case MAT and MAP.

Keywords: Diospyros celebica, leaf morphology, climate, identification, random forest

\section{Introduction}

Indonesia's tropical rain f orest region contains an extremely high diversity of plant species and forest formations. Ebony (Diospyros spp.) is a group of forest plants from the Ebenaceae spread across various Indonesian regions. Of the seven types of ebony plants that grow in Indonesia, Diospyros celebica Bakh can only grow naturally on the island of Sulawesi (Hendromono and Allo. 2008). From the economic benefits, Diospyros celebica has good wood quality, so it has a high selling value. This type of wood is widely used for light to heavy construction materials and also necessary raw materials for Indonesia's timber industry (Kinho. 2013; Kinho et al. 2011). The increasing demand for wood that is not matched by the success of cultivation causes this species' population to decline, both in terms of productivity and habitat. Therefore, in 1998 International Union for Conservation of Nature included Diospyros celebica plants in the vulnerable category (IUCN. 2010).

The population decline of Diospyros celebica in Sulawesi's natural forests is currently getting more worrying, so rescue efforts are needed (Bostoni. 2005). Overcoming population decline can 
be done through in-situ conservation, ex-situ conservation, cultivation, and sustainable use (Sunaryo. 2002). According to Allo (2002) the growth and reproduction process of Diospyros celebica will run well if it is supported by certain environmental conditions, such as altitude and climatic conditions in an area.

One indicator that can be used to see plant growth's success is to look at the leaves' shape and size. Leaves are plant organs that have a role in photosynthesis. Thus, leaf shape and size are essential factors in influencing plant growth (Tsukaya. 2005). The shape and size of the leaves are very dependent on the climatic conditions around the plant. Guerin et al. (2012) explained that climate change is capable of causing consistent morphological shifts in plants. The most visible changes are in the shape and size of the leaves. This morphological shift event is usually closely related to phenotypic plasticity, namely, the individual's ability to modify behavior, physiology, and morphology in response to changing environmental conditions (Bradshaw and Holzapfel. 2006). Therefore, it is essential to understand the extent to which climate impacts can affect plant growth to increase productivity in plants.

Research related to leaf morphology is widely performed. Manik et al. (2016) extracted the morphological features of Anthocephalus cadamba leaves using the support vector machine (SVM) as a classification technique. The results show that morphological features such as rectangularity, roundness, compactness, solidity, convexity, elongation, and eccentricity represent characteristic forms of disease symptoms in plants. Li et al. (2015) conducted a morphological analysis of Ziziphus jujuba Mill leaves in China. The morphological characteristics found are broad area, perimeter, and leaf venation. The results show a linear relationship between area, venation density, and leaf perimeter with temperature and rainfall. Another study conducted by Minh et al. (2019) analyzed the relationship between climate elements and the leaf morphology of the Huperzia Serrata plant in the Vietnam region. The results indicate that leaf size is strongly correlated with temperature and rainfall and weakly correlated with humidity.

Knowing where a plant grows naturally can help botanists restore a plant population, so identifying or classifying leaf morphology based on the region of origin can be done. Random Forest is a classification technique that can be used to classify various types of data and classification is performed by merging decision trees through training in sample data. The use of increasing trees gives better accuracy (Ghimire et al. 2010). In cases of pattern recognition, the random forest method performs significantly better than other methods. Caglayan et al. (2013) compared several classification techniques such as the k-nearest neighbor, SVM, naive Bayes, and random forest of plant type recognition using leaf shape and color features. The results show that the random forest algorithm produces the best accuracy (96\%).

The motivation for this research is the lack of available research on Diospyros celebica trees, especially research that provides information related to leaf morphological feature extraction. This study aims to extract the morphological features of ebony leaves and analyze the relationship of those features with climate variables. The extraction of leaf morphological features produces several features, and they are classified to predict the origin of Diospyros celebica trees. They are also classified to obtain the characteristic features in each region. This study uses the random forest algorithm classification technique. Furthermore, this study uses an oversampling method to improve random forest classification accuracy on unbalanced data distribution. Oversampling technique can balance data distribution to reduce the effect of an unbalanced class distribution by replicating the sample in the minority class to as many as the numbers of data in the majority class (Chawla et al. 2002). 


\section{Materials and methods}

\section{Study sites and leaf sampling}

Diospyros celebica leaf sampling was conducted by the Institut Pertanian Bogor (IPB and World Resources Institute (WRI) teams across forest areas in several districts in South Sulawesi, Central Sulawesi and West Sulawesi in 2019. Districts in South Sulawesi include (East Luwu, Bone, Gowa, Maros and Barru. Districts in Central Sulawesi; Donggala, Parigi Moutong, Poso, and Morowali. Districts in West Sulawesi; Mamuju) as shown in Figure 1 (Karlinasari et al. 2020). Leaf sampling method was conducted randomly on each tree by taking 5 to 7 leaves from each tree. The number of trees used as a sample was 5 to 10 trees in each location, however, according to the number of trees available in that area. Each sampling location has a different number of stands, for example the stands in Diospyros celebica West Sulawesi which have the least number of trees among the others. Amount climate data for the last 5 years (January 2015-December 2019) were collected for each sampling location. Climatic data include mean annual precipitation, mean annual temperature, mean annual sunshine duration, mean annual wind speed, and mean annual air humidity. Data was obtained from the official website of the Meteorology, Climatology and Geophysical Agency (BMKG: http://dataonline.bmkg.go.id). Climate data consists of five variables: temperature, rainfall, humidity, wind speed, and sunlight intensity (numerical data). Some districts where the samples were taken did not have a climatology station (East Luwu, Barru, Parigi Moutong, and Mamuju). Thus, this study used climate data from the closest areas to represent locations without a climatology station.

Furthermore, we calculated the average climate value for each province to be included in the analysis. In this study, we conducted an analysis based on the province where the plants were grown, thus because the climate data from the 14 sampling locations available were minimal, making it difficult to analyze them based on the 14 sampling locations. Therefore, analyzing it based on the province of origin is the best option. According to the climate data that has been collected, the provinces of Central Sulawesi and West Sulawesi tend to experience drought pressure because the mean annual precipitation of the sampling locations in these provinces is quite low. South Sulawesi Province has much higher precipitation and a slightly lower temperature than the other two provinces. Complete information regarding climatic conditions in each province is presented in Table 1. 


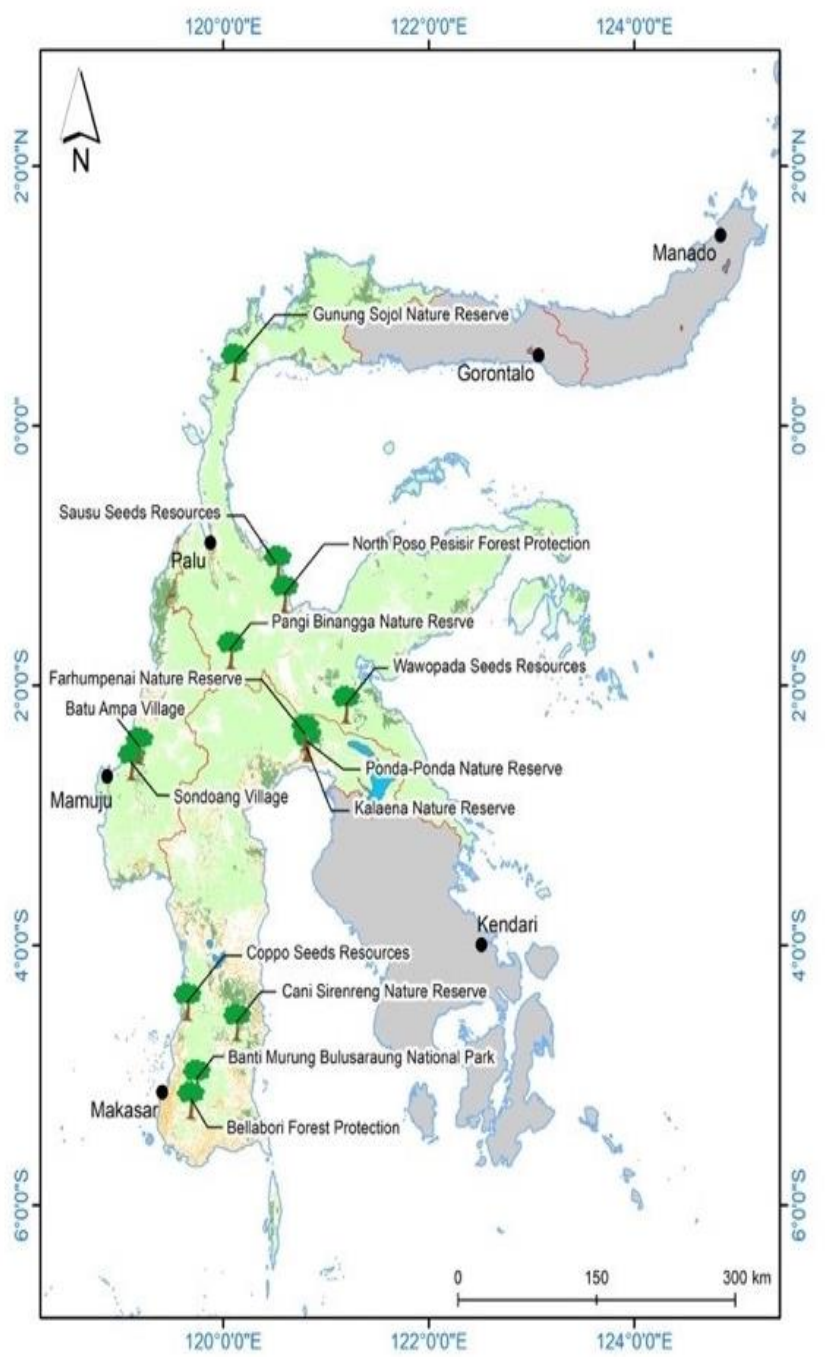

\section{SAMPLING SITE}

\section{LEGEND}

- capital of the PROVInCE

- EBONY SAMPLE

PROVINCIAL BOUNDARY

LAKE

PLANTATION

FOREST

SETTLEMENT

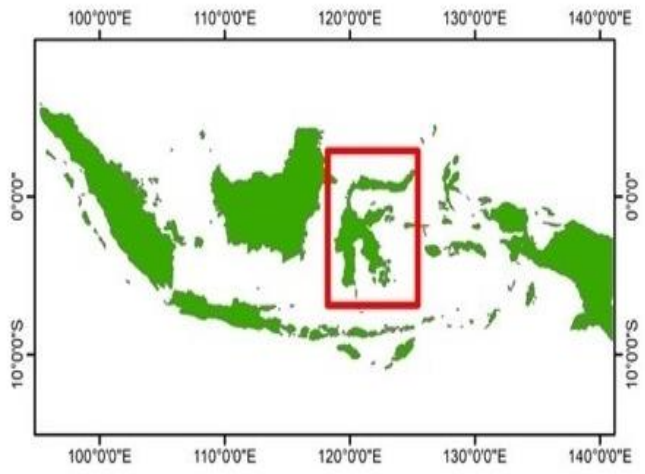

Fig. 1 Distribution of 14 sampling locations for Diospyros celebica leaves (Karlinasari et al. 2020)

Table 1. Climatic characteristics (January 2015-December 2019) of the sampling locations for Diospyros celebica leaves in the three provinces

\begin{tabular}{ccccccc}
\hline Province & Parameter & $\begin{array}{c}\text { Temperature } \\
\left({ }^{\circ} \mathbf{C}\right)\end{array}$ & $\begin{array}{c}\text { Humidity } \\
(\mathbf{\%})\end{array}$ & $\begin{array}{c}\text { Precipitation } \\
(\mathbf{m m})\end{array}$ & $\begin{array}{c}\text { Sunshine } \\
\text { duration }(\mathbf{h})\end{array}$ & $\begin{array}{c}\text { Wind } \\
\text { speed } \\
(\mathbf{m} / \mathbf{s})\end{array}$ \\
\hline South & Count & 11,083 & 11,083 & 11,083 & 11,083 & 11,083 \\
Sulawesi & Mean & 27.44 & 80.30 & 11.02 & 6.40 & 1.61 \\
& Std & 1.051 & 7.63 & 18.28 & 3.22 & 0.83 \\
Central & Count & 7,091 & 7,091 & 7,091 & 7,091 & 7,091 \\
Sulawesi & Mean & 27.65 & 80.03 & 4.56 & 5.75 & 1.65 \\
& Std & 0.93 & 5.27 & 9.98 & 2.74 & 0.75 \\
West & Count & 1,551 & 1,551 & 1,551 & 1,551 & 1,551 \\
Sulawesi & Mean & 27.86 & 79.57 & 6.45 & 6.66 & 1.85 \\
& Std & 0.84 & 4.55 & 11.11 & 2.52 & 0.86 \\
\hline
\end{tabular}




\section{Measurement of leaf morphological parameters}

Approximately five to seven middle leaves were selected from each shoot for examination and a chemical cleaning process (Sack et al. 2012). Each leaf was carefully cut from the stem and dried before measurement (Perez et al. 2013; Ellis et al. 2009). After the leaf drying process, the next step is scanning each Diospyros celebica leaf by selecting the condition of the leaves that are still intact and not hollow. Leaf morphological features were measured using (the image analysis software) Image-J (Abramoff et al. 2004). The leaf morphological features extracted in this study were limited to shape features. Leaf samples taken were 5 to 7 outer leaves on each tree of each tree taken randomly. The ebony species used in this study was the celebica type. The image data that has been taken are 777 pictures, divided into 367 pictures of Diospyros celebica leaves, South Sulawesi, 327 pictures of Central Sulawesi, and 81 pictures of West Sulawesi.

\section{Data preparation}

The first step in image preprocessing is cropping each scanned photo. This step aims to separate the leaves on the petiole so that the picture can be processed easily at a later stage. After cropping all leaf image data, the grayscale process was carried out. The purpose of carrying out the grayscale process is to have less information in the image than color images (Burger and Burge. 2013; Putzu et al. 2014). After the grayscale process, the threshold process was carried out. Thresholding is a segmentation method used to separate objects that are considered foreground and background.

In addition to the preprocessing carried out on leaf images, preprocessing is also carried out on climate data. Preprocessing was carried out because there were several data missing values. The missing values may have been caused by engine damage at the climatology stations, human error, or other elements. Preprocessing the missing values was completed by filling in the absence data with the aggregate data's mean value of total data.

\section{Data analysis}

Statistical analysis was performed using Python software (version 3.7.4) and IBM SPSS Statistics. The climate data must be first estimated in value because the leaf sampling and climate data patterns are not time series (homogeneous). Estimation is a method by which we can estimate a population's value using the sample's value. The data needs to be estimated so that it can be processed further in the correlation analysis. The method used to estimate climate data is using the Autoregressive Integrated Moving Average method. Furthermore, the correlation test and significance test were carried out to see the relationship between leaf size and climate variables. Finally, leaf morphological feature extraction results were classified using the random forest method to estimate the origin of leaves according to their region of origin. Random forest classification is carried out by merging trees by conducting training on sample data, using numerical data on leaf morphological features. The n_estimators value initially tried at $10,15,20$, and 25 to get the number of n_estimators with the best and stable accuracy, which would be the default of random forest classification. It means that the number of trees built by the random forest algorithm was $10,15,20$, and 25 , before taking maximum votes or taking average predictions.

\section{RESULTS}

Several features must be extracted first to recognize objects in an image. The features extracted on the leaves are leaf area, perimeter, length, width, convex hull area and convex hull perimeter. Another feature used is the morphological derivative feature. This derived feature is obtained from the proportion of the main features. Such as roundness, solidity, eccentricity, convexity, elongation and rectangularity. An illustration of leaf morphological feature extraction is presented in (Fig $2 \mathrm{~A}$ and $2 \mathrm{~B}$ ). 


\section{A}

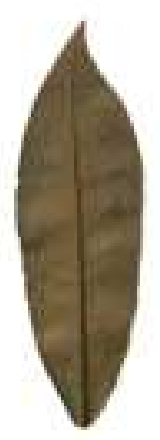

1

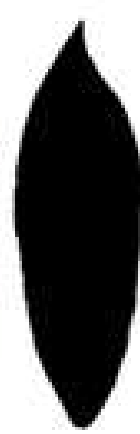

2

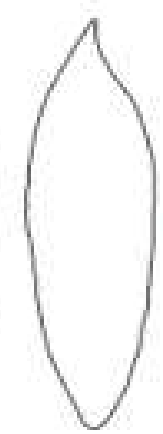

3

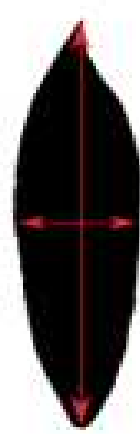

4

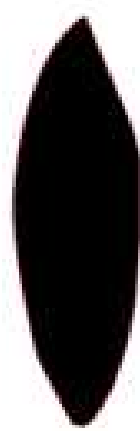

5

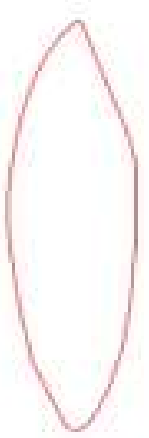

6

Fig. 2A Main morphological features of Diospyros celebica leaves; (1) original image, (2) area, (3) perimeter, (4) length and width, (5) convex hull area, and (6) convex hull perimeter.

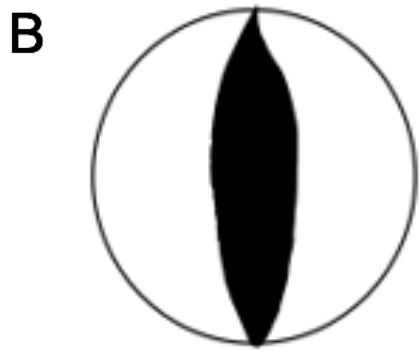

7

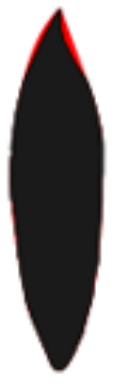

8

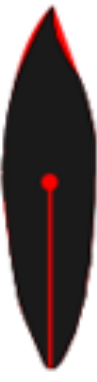

9

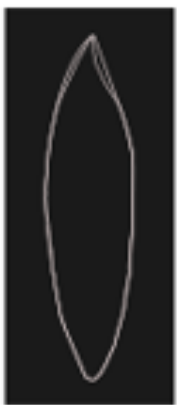

10

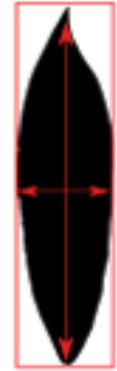

11

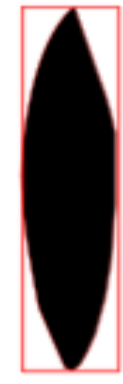

12

Fig. 2B Derivative features of leaf morphology; (7) roundness, (8) solidity, (9) eccentricity, (10) convexity, (11) elongation and (12) rectangularity.

To describe the position of the data in each province, this study we use Principal Component Analysis (PCA). PCA is a technique for simplifying data, so this technique is often used to reduce the dimensions/features of data without significantly reducing the fact of the data (Shlens, 2009). The following are the results of the application of PCA on the Diospyros celebica leaf data with the provincial target class presented in Figure 3. Based on the PCA results, it can be seen that the distribution of instances per label class is quite good, especially in the classes of South Sulawesi and Central Sulawesi. This can be seen in each label of the class which is related between instances with the same label class. It is slightly different from the data in the West Sulawesi class, where the data distribution is clustered between South Sulawesi and Central Sulawesi, so it is more difficult to see the data distribution pattern. This is presumably because the amount of leaf data from West Sulawesi is not comparable with leaf data from South Sulawesi and Central Sulawesi. By looking at this information, the oversampling technique will be very useful in determining the accuracy of the classification results later. 


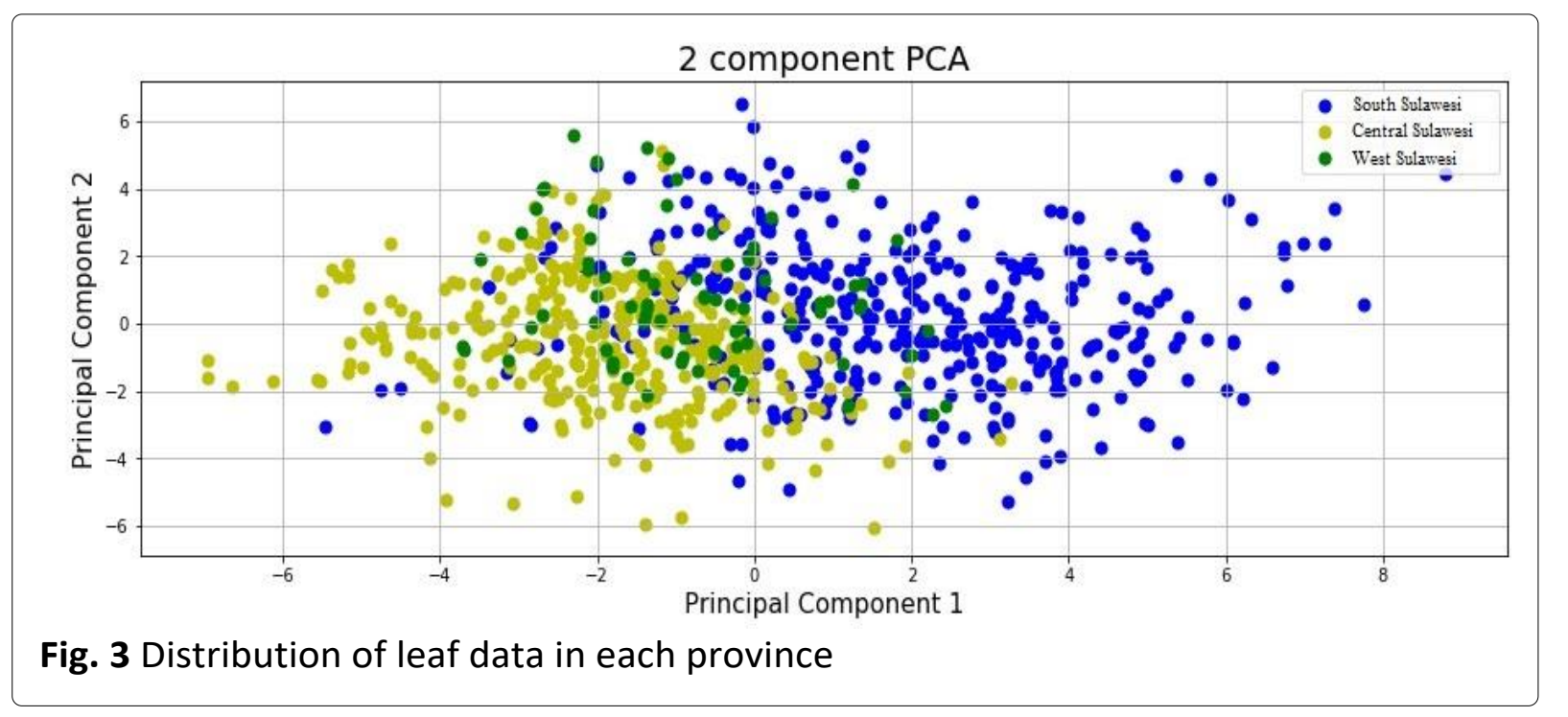

\section{Climate variables}

Based on descriptive statistics, MAP, MAT and SuH showed significant differences in each province. In the 5 years evaluated, Central Sulawesi had the lowest MAP (4.565 mm). This is lower than West Sulawesi $(6.452 \mathrm{~mm})$ and South Sulawesi $(11.026 \mathrm{~mm})$. For MAT, Central Sulawesi $\left(27.865^{\circ} \mathrm{C}\right)$, West Sulawesi $\left(27.652^{\circ} \mathrm{C}\right)$, and South Sulawesi $\left(27.440^{\circ} \mathrm{C}\right)$ were ranked first, second, and third, respectively. For SuH, that of South Sulawesi was the highest (6.667 h). This was much higher than those of West Sulawesi $(6.047 \mathrm{~h})$ and Central Sulawesi $(5.759 \mathrm{~h})$. For Hu and WS, no significant differences were noted between South Sulawesi, Central Sulawesi and West Sulawesi.

\section{Influences of climatic variables on leaf morphology}

Leaf size of Diospyros celebica which varies from province to province, will be investigated through Pearson's correlation analysis and significance test. Correlation analysis is used to see the relationship between morphological features and their correlation with climate variables. The correlation coefficient has a value of -1 to 1 . If the value was closer to 1 , it signified a more significant correlation between the two variables, while the relationship's negative value is inversely proportional. If positive, then the relationship between the two is directly proportional (Kirch. 2008). Some of the distribution of several leaf morphological features found are successfully extracted (numerical data), classified based on the province where the sample was taken, which is presented in the boxplot form in (Fig 4A and 4B). 
A
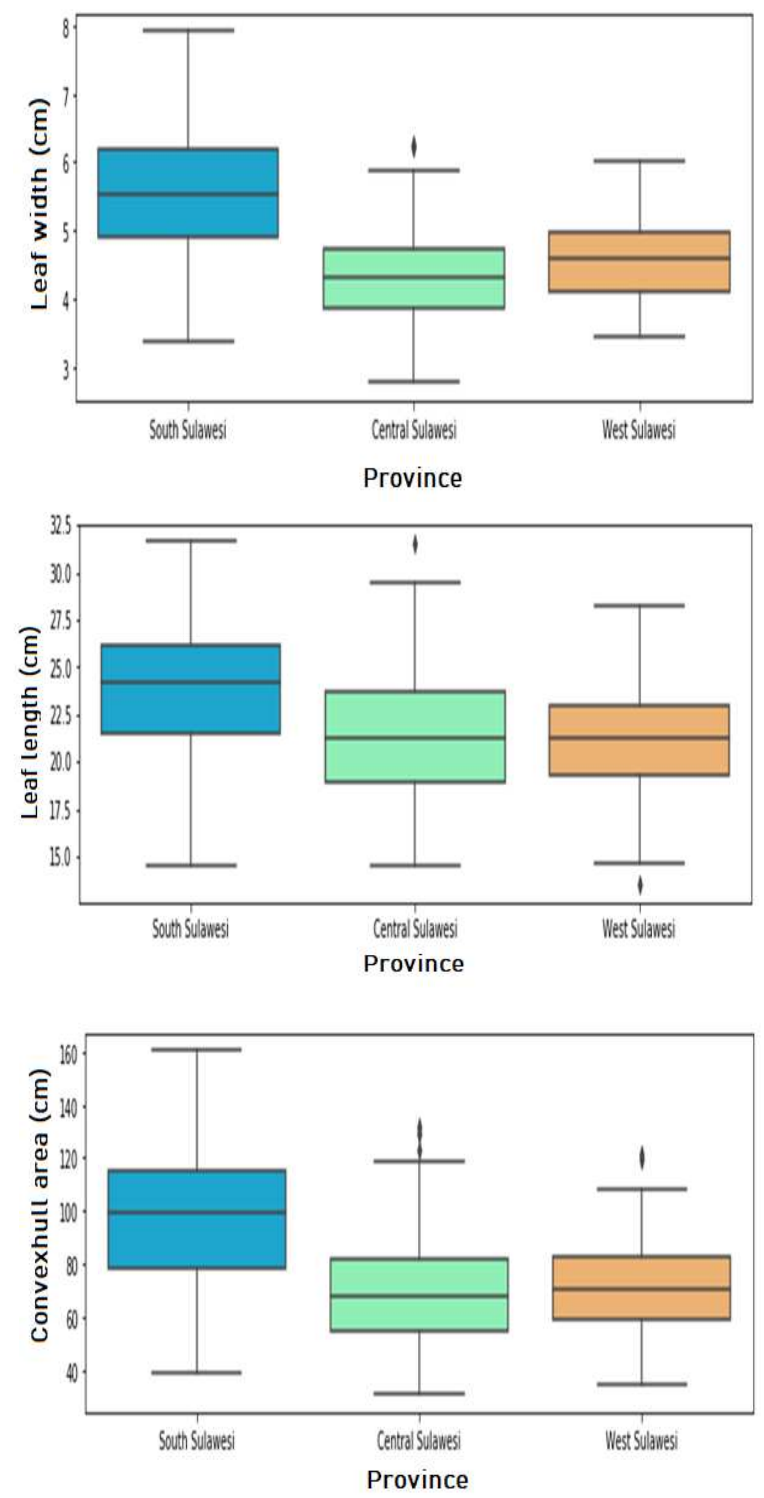
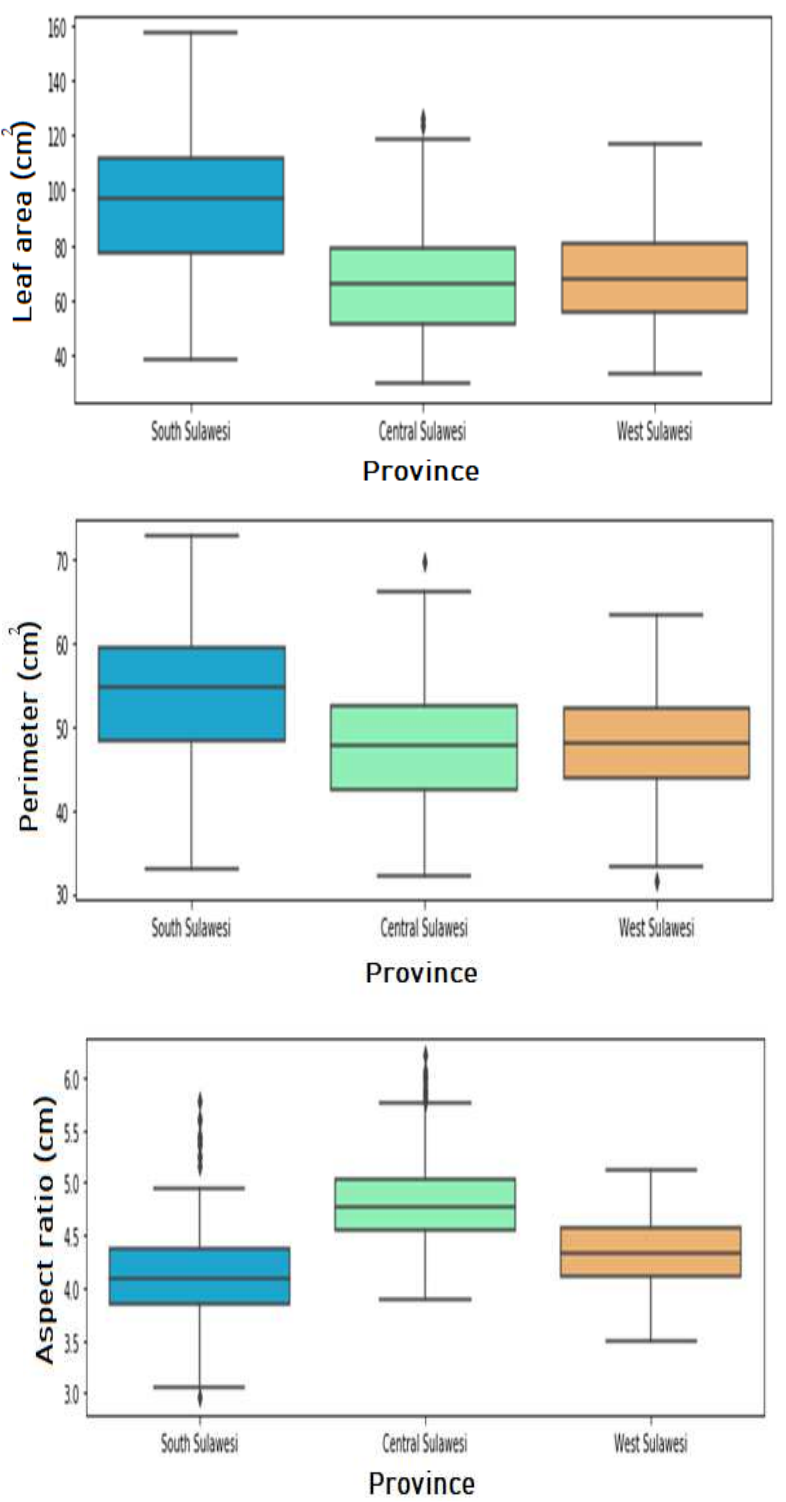

Fig. 4A Boxplot original features of leaf morphology in each province 
B
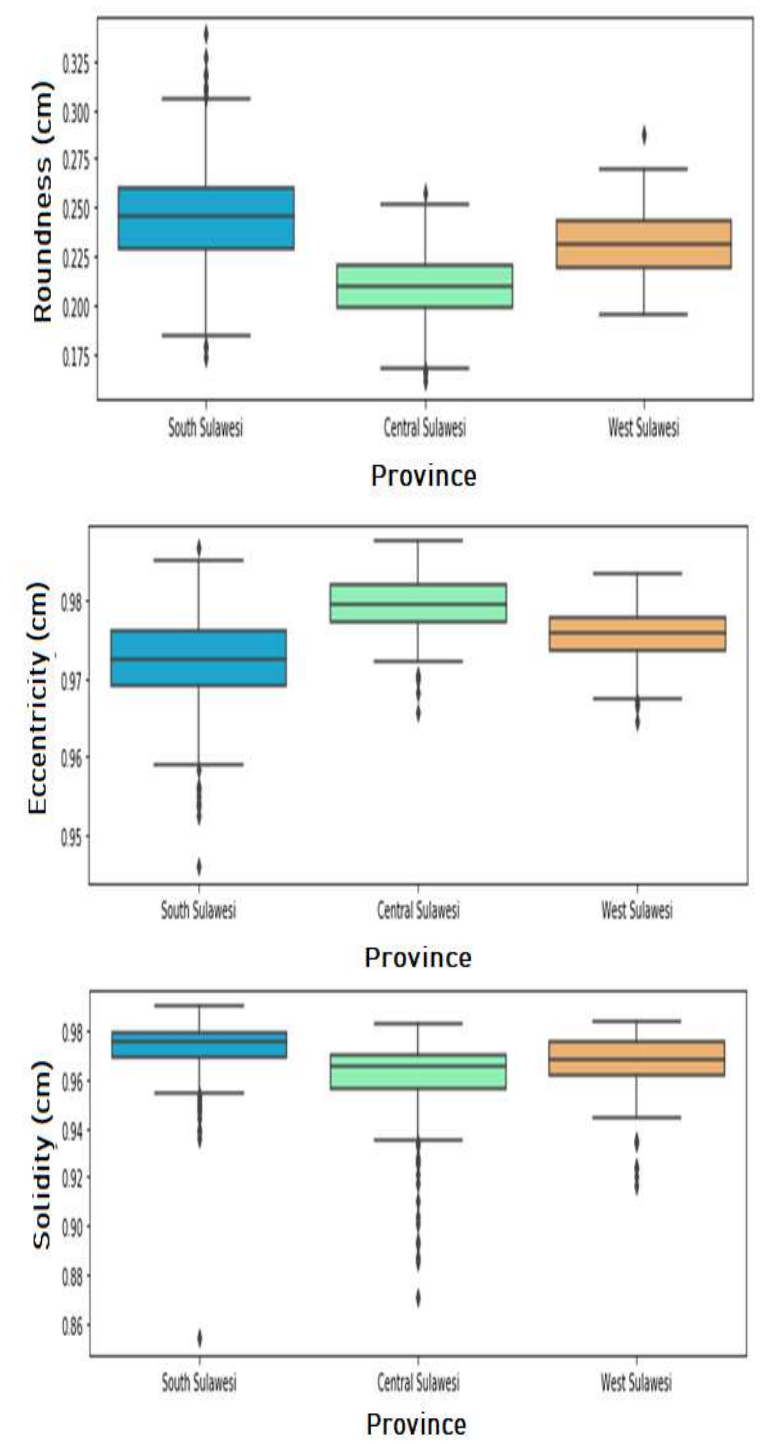
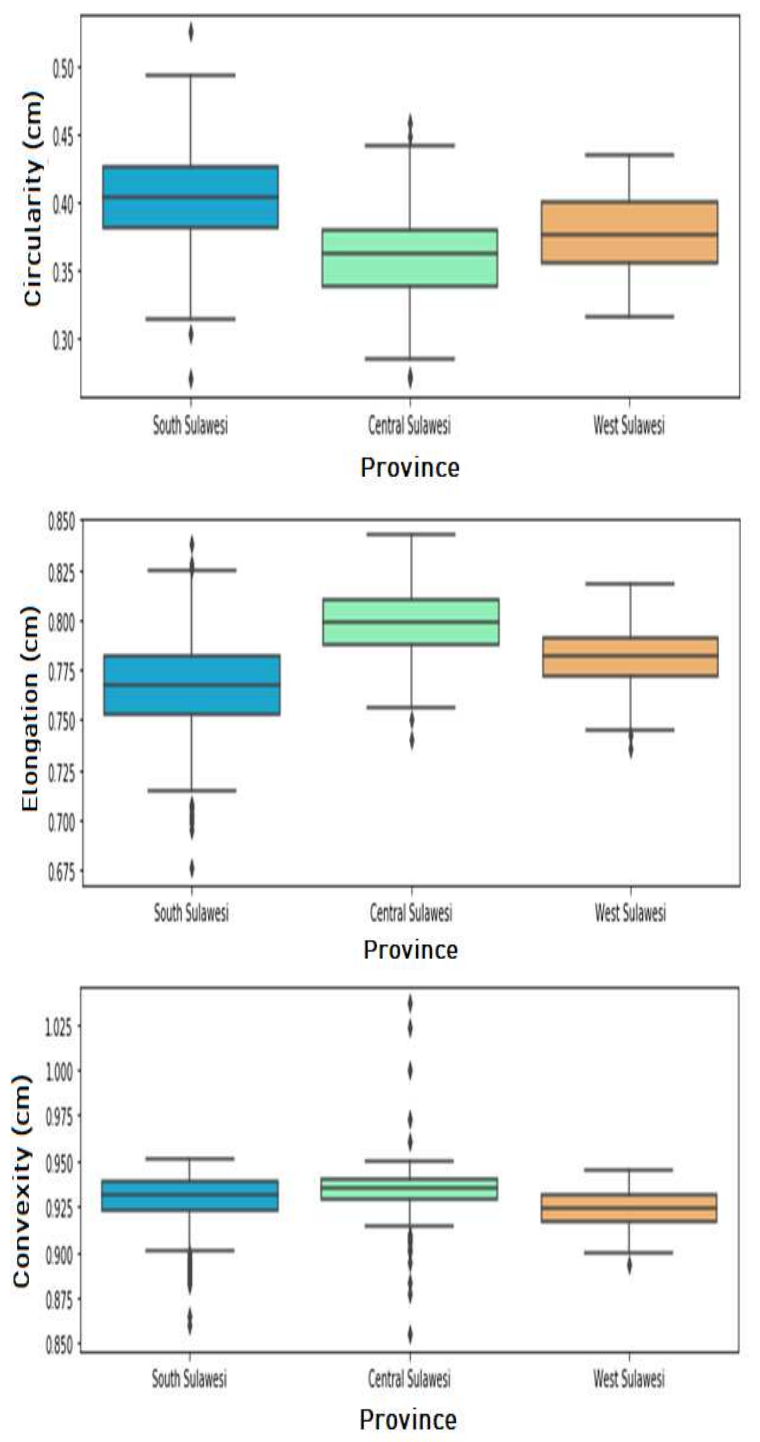

Fig. 4B Boxplot derivative features of leaf morphology in each province

\section{Influence of mean annual precipitation on leaf morphology}

Climatic conditions vary widely in the three provinces where the samples were taken, especially for MAP. Diospyros celebica leaves differ in size and shape due to environmental influences. Morphological characteristics such as area $\left(r^{2}=0.29, p=0.01\right)$, width $\left(r^{2}=\right.$ $0.35, p=0.04)$, circularity $\left(r^{2}=0.37, p=0.04\right)$, roundness $\left(r^{2}=0.39, p=0.01\right)$, and convex hull area $\left(r^{2}=0.28, p=0.032\right)$ have a positive linear relationship with MAP. A positive linear relationship means that the higher the MAP, the higher the value of these morphological features. Other morphological features such as eccentricity $\left(r^{2}=-0.37, p=0.022\right)$, aspect ratio $\left(r^{2}=\right.$ $-0.40, p=0.015)$, and elongation $\left(r^{2}=-0.38, p=0.01\right)$ have a negative linear relationship with MAP. A negative linear relationship means that the higher the MAP, the lower the value of these features. It is demonstrated in the boxplot in (Fig 4A and 4B) that the data distribution of the five features that have the highest positive correlation (area, width, circularity, roundness and convex hull area) in South Sulawesi is in accordance with the MAP in South Sulawesi (it scored the highest among the three provinces). This condition is in line with MAP in South Sulawesi, which has the highest rainfall in the other two provinces in the last five years (Table 1). 


\section{Influence of mean annual temperature on leaf morphology}

Five leaf features are negatively correlated with MAT; width $\left(r^{2}=-0.28, p=0.02\right)$, area $\left(r^{2}=-0.22, p=0.033\right)$, roundness $\left(r^{2}=-0.30, p=0.01\right)$, circularity $\left(r^{2}=-0.30, p=\right.$ $0.01)$, and solidity $\left(r^{2}=-0.23, p=0.027\right)$. (Table 1$)$ shows that the MAT in Central Sulawesi has the highest value compared with the other two provinces. The lowest MAT value is in South Sulawesi. These values are in line with the distribution of the values of the five negatively correlated features (area, width, circularity, roundness, and convex hull area), where the five morphological features from Central Sulawesi had the lowest average feature values compared with the other two provinces. For the three positively correlated features (aspect ratio, eccentricity and elongation), the Diospyros celebica leaves from Central Sulawesi had the highest average feature value following the temperature trend in Central Sulawesi, which had the lowest average value compared to the other two provinces.

\section{Influence of sunshine duration on leaf morphology}

Some leaf features positively correlated with SuH, including area $\left(r^{2}=0.25, p=0.011\right)$, width $\left(r^{2}=0.26, p=0.01\right)$, perimeter $\left(r^{2}=0.23, p=0.01\right)$, length $\left(r^{2}=0.20, p=0.00\right)$, and convex hull area $\left(r^{2}=0.25, p=0.019\right)$. Based on the analysis, these four Diospyros celebica leaf morphological features from South Sulawesi had the highest average feature values compared with the two other provinces. This was in line with the SuH condition, where the average values were the highest in South Sulawesi than in the other two provinces.

\section{Influence of wind speed on leaf morphology}

WS was one of the climatic factors that were quite influential on leaf morphology (Zhang et al. 2018). Leaf morphological features such as roundness $\left(r^{2}=-0.29, p=0.021\right)$, circularity $\left(r^{2}=-0.36, p=0.01\right)$, and solidity $\left(r^{2}=-0.20, p=0.031\right)$ negatively correlated with WS. Other features such as aspect ratio $\left(r^{2}=0.29, p=0.00\right)$, eccentricity $\left(r^{2}=0.29, p=0.044\right)$, and elongation $\left(r^{2}=0.30, p=0.00\right)$ positively correlated with WS. Based on the boxplot in (Fig $5 A$ and $5 B$ ) the roundness, circularity, and solidity features from South Sulawesi had the highest average values. The lowest average values were in Central Sulawesi. By contrast, the morphological features of aspect ratio, eccentricity, and elongation had negative correlations, and the highest average morphological feature values were in Central Sulawesi. The lowest average values were in South Sulawesi. These findings were in line with South Sulawesi's WS pattern that had the lowest average value. The highest WS pattern was in Central Sulawesi.

\section{Influence of humidity on leaf morphology}

Based on the analysis of the correlation matrix, the Hu was a climate variable that was less correlated with all morphological characteristics of ebony leaves. Descriptive statistical analysis showed that the average $\mathrm{Hu}$ in the last 5 years in each province was $80.30 \%, 80.03 \%$, and $79.57 \%$. There was no significant difference in the average Hu between provinces, so it had little effect on leaf morphology differences.

\section{Random Forest Classification}

Random forest method predicts the response of observation by using all of the results of the decision tree predictions. In the classification case, the majority vote technique was used to determine the prediction result (Breiman, 2001). This study conducted a random forest classification for morphological data of leaves into three provincial classes (South Sulawesi, Central Sulawesi, and West Sulawesi), with the data for each class sequenced (369, 327 and 81). The distribution of training data and test data in the random forest classification was 80:20. Generally, a higher number of trees improve performance and make leads to more stable 
predictions. The experiments in this study, at n_estimators $=20$, began to produce a stable accuracy value of $73.07 \%$. Thus, the default n_estimators of 20 was used for subsequent random forest classifications using the oversampling method.

The oversampling technique was utilized to overcome imbalanced data by resampling the elimination of minority classes (Central Sulawesi and West Sulawesi) at random until the number was equal to the majority class (South Sulawesi) (Chawla et al. 2001). The highest amount of training data was in the South Sulawesi class (369). The three classes of Sulawesi provinces were generalized so each class of data equaled 369. The random forest classification accuracy was tested with oversampling. Test data were utilized to obtain a confusion matrix that had greater accuracy than the usual random forest method (94.59\%).

\section{DISCUSSION}

In this study, most of the leaf sizes of Diospyros celebica from Central Sulawesi had relatively smaller leaf sizes. On the other hand, Diospyros celebica leaves in South Sulawesi were somewhat more extensive than the other two provinces' leaves. Several important points were obtained based on the correlation analysis and significance tests that have been carried out. MAP and MAT are climate variables that are quite influential on the morphology of Diospyros celebica leaves. In contrast, the other three climate variables $(\mathrm{SuH}, \mathrm{WS}$, and $\mathrm{Hu}$ ) are less correlated with ebony leaves' morphology. It indicates that the leaf size of Diospyros celebica is the result of the interaction between rainfall intensity and high and low temperature in an environment. Based on the analysis, it can be concluded that Diospyros celebica has adapted to local climatic conditions especially at low temperatures, limited sunshine intensity, wind varying WS, and limited rainfall.

The random forest method was used to classify Diospyros celebica plants based on province. Classification results were judged by the accuracy amount, as well as several other parameters including precision, recall, and F1 score. Precision is the ratio of true positive predictions compared with the overall positive predicted results. Recall (or sensitivity) is the measurement of true positive proportions that are correctly identified. F1 score is a weighted average comparison of precision and recall (Fawcett, 2006; Lin et al. 2014). Based on the evaluation, the ordinary random forest classifier had an average precision value of 0.80 and a recall value of 0.667 . The difference in value between precision and recall was large enough that it indicated the classification model was not optimal. For random forest using oversampling, the average precision value was 0.923 and the average recall value was 0.896 . The difference in value between precision and recall was small enough that it indicated the classification model was optimal.

The analysis of leaf morphological feature characteristics was performed by looking at the important features resulting from the random forest classification result. A total of 15 morphological features were used. Three features most helped the model with classification: roundness, circularity, and width. These three features affected approximately $35 \%$ of the classification results from the random forest classification. In addition, based on the analysis of the average leaf size and import features from the random forest classification there are two other features that can be used to identify the origin of ebony. namely aspect ratio and leaf area. Thus, these five features can be used as the primary identifier of the origin of Diospyros celebica wood.

The results in this study indicate that the genetic diversity of Diospyros celebica populations still revealed a high diversity level as assessed by RAPD markers ( $\mathrm{He}=0.29-0.38$ ) as reported by Widyatmoko et al. (2011) and Wulandari et al. (2017). However, another study in a single population level reported a low genetic diversity $(\mathrm{He}=0.47-0.50)$ as assessed by microsatellite marker (Larekeng et al. 2019). Currently, a population genetic study across Celebes has not been reported, although such an initiative is still on progress. Since our study was based on population levels across natural distribution, the influence of sites was also expected to be significant that 
may be expressed in the clustering of populations. This clustering of populations could be explained based the results of Karlinasari et al. (2020) in which ebony wood from West Celebes differed from most of the wood from South Celebes, however, it was only slightly different from ebony wood from Central Celebes based on NIR spectra data. Our analysis based on leaf morphology was in line with NIR spectra data that there were several leaf traits could be used to differentiate the origin such as feature roundness, width, aspect ratio, area, and circularity.

\section{CONCLUSION}

Diospyros celebica is a wood species endemic to Sulawesi, which spreads from the lowlands to the highlands in various climatic variations. evaluated the leaf morphology of one ebony species that is grown in different environments in 14 Sulawesi locations. Based on the correlation analysis, it can be seen that some of the leaf morphological characteristics of Diospyros celebica are quite correlated with MAT and MAP. On the other hand, three other climate variables, such as SuH, WS, and Hu, have a weak correlation with morphological features. In dry weather, the leaves of Diospyros celebica tend to have relatively small leaf sizes. In contrast to the wetter weather, the leaves will have a much larger shape and size. This larger leaf size usually indicates good growth of a plant compared to smaller leaves. Therefore, this study's results recommend that the conservation of Diospyros celebica be carried out in places with wetter climatic conditions and lower temperatures, such as climatic conditions in South Sulawesi province. Furthermore, the random forest classification model classifies the leaf morphological data by applying the oversampling technique into three provincial classes, with the classification results obtained with an accuracy of $94.59 \%$. Morphological features (roundness, width, aspect ratio, area, and circularity) are the features that most help the model in classifying leaves based on provincial classes. Therefore, these features can be used as the main characters in identifying the origin of Diospyros celebica.

\section{Acknowledgments}

The authors are thankful for access to research biological materials collected under the Ebony Project managed by the IPB and WRI teams.

\section{Author's contributions}

All authors contributed equally to this work.

\section{Availability of data and materials}

The climate data in this study were taken from the official website of the Meteorology, Climatology and Geophysical Agency (BMKG: http://dataonline.bmkg.go.id).

\section{Declarations}

\section{Ethics approval and consent to participate}

Not applicable.

\section{Conflicts of interest}

The authors declare no conflicts of interest.

\section{Author details}

1,2Department of Computer Science, Faculty of Mathematics and Natural Sciences, IPB University, Bogor, Indonesia.

${ }^{3}$ Department of Silviculture, Faculty of Forestry and Environment, IPB University, Bogor, Indonesia 


\section{References}

Abràmoff, M. D., Magalhães, P. J., Ram, S. J. (2004). Image processing with ImageJ. Biophotonics international. 11(7), 36-43.

Allo MK. 2002. Eboni dan habitatnya. Berita Biologi - Manajemen Eboni 6(5): 259-265.

Bastoni. (2005). Kajian Ekologi dan Silvikultur Ramin di Sumatera Selatan dan Jambi. Bogor: Pusat Penelitian dan Pengembangan Hutan dan Konservasi Alam, ITTO dan PPD.

Bradshaw, W. E., Holzapfel, C. M. (2006). Evolutionary response to rapid climate change. Science. 312, 1477-1478.

Breiman, L. (2001). Random forests. Machine Learning. 45, 5-32.

Burger, W., Burge, M. J. (2013). Principles of Digital Image Processing: Advanced Methods. Springer, London.

Caglayan A., Guclu O., Can A.B. 2013. A plant recognition approach using shape and color features in leaf images. Di dalam: International Conference on Image Analysis and Processing. 161-170.

Chawla, N. V., Bowyer, K. W., Hall, L. O., Kegelmeyer, W. P. (2002). SMOTE: Synthetic minority over-sampling technique. Journal of Artificial Intelligence Research. 16, 321-357.

Ellis, B., Daly, D. C., Hickey, L. J., Johnson, K. R., Mitchell, J. D., Wilf, P., Wing, S. L. (2009). Manual of Leaf Architecture. Ithaca: Cornell University Press.

Fawcett, T. (2006). An introduction to ROC analysis. Pattern Recognition Letters. 27, 861-874.

Ghimire B, Rogan J, Miller J. 2010. Contextual land-cover classification: Incorporating spatial dependence in land-cover classification models using random forests and the getis statistic. Remote Sensing Letters. 1: 45-54.

Guerin, G. R., Wen, H., Lowe, A. J. (2012). Leaf morphology shift linked to climate change. Biology Letters. 8(5), 882-886.

Hendramono \& Allo MK. 2008. Konservasi sumber daya genetika eboni di Sulawesi Selatan (Ebony genetics resources conservation in South Sulawesi). Info Hutan 5(2):177-187.

[IUCN Red List] The International Union for Conservation of Nature Red List of Threatened Species. 2010. World Conservation Monitoring Centre (1998).

Li, X., Li, Y., Zhang, Z., Li, X. (2015). Influences of environmental factors on leaf morphology of Chinese jujubes. PLOS ONE. 10(5).

Karlinasari L, Noviyanti N, Purwanto YA, Majiidu M, Dwiyanti FG, Rafi M, Damayanti R, Harnelly E, Siregar IZ (2020). Discrimination and determination of extractive content of ebony (Diospyros celebica Bakh.) from Celebes island by near-infrared spectroscopy. Forests. 2 (1):6. https ://doi.org/10.3390/f1201 0006.

Kinho, J. (2013). Mengembalikan Kejayaan Eboni di Sulawesi Utara. Manado: Balai Penelitian Kehutanan.

Kinho, J., Suryawan, A., Setyawati T. (2011). "Struktur dan komposisi vegetasi habitat Eboni (Diospyros sp.) pada hutan dataran rendah di Cagar Alam Tangkoko, in Ekspose Hasil Litbang Balai Penelitian Kehutanan Manado Tahun 2011, 167 - 180. 
Kirch W. (2008). Pearson's Correlation Coefficient. (eds) Encyclopedia of Public Health. Springer, Dordrecht. https://doi.org/10.1007/978-1-4020-5614-7_2569.

Larekeng, S.H., Restu, M., Susilowati A., Rachmat H.H. (2019). Genetic Diversity of Parental and Offspring Population in Ebony (Diospyros celebica Bach) Revealed by Microsatellites Marker. International Journal on Emerging Technologies 10(2): 178-185.

Lin, K. B., Weng, W., Lai, K., Lu, P. (2014). "Imbalance data classification algorithm based on SVM and clustering function", in 9th International Conference on Computer Science \& Education (ICCSE) 2014. 544-548.

Manik, F. Y., Herdiyeni, Y., Herliyana, E. N. (2016). Leaf morphological feature extraction of digital image Anthocephalus Cadamba. Telkomnika. 14(2), 630.

Minh, N. T. A., Van, D. N., Van, T. T. (2019). Geographical variation in morphological leaf traits of Huperzia serrata (lycopodiaceae) from Vietnam. TAP CHI SINH HOC. 41(4).

Pérez-Harguindeguy, N., Díaz, S., Garnier, E., Lavorel, S., Poorter, H., Jaureguiberry, P. (2013). New handbook for standardised measurement of plant functional traits worldwide. Australian Journal of Botany. 61(3),167-234.

Plotze, R. D. O., Bruno, O. M. (2009). Automatic leaf structure biometry: computer vision techniques and their applications in plant taxonomy. International Journal of Pattern Recognition \& Artificial intelligence, 23(02), 247-262.

Putzu, L., Caocci, G., Di Ruberto, C. (2014). Leucocyte classification for leukaemia detection using image processing techniques. Artificial Intelligence in Medicine, 62(3), 179-191.

Sack, L., Scoffoni, C., McKown, A. D., Frole, K., Rawls, M., Havran, J. T., Tran, H., T. (2012). Developmentally based scaling of leaf venation architecture explains global ecological patterns. Nature Communications. 3, 837.

Shlens, J. M. (2009). A Tutorial on Principal Component Analysis, Version 3.01. Center for Neural Science: New York University.

Sunaryo. 2002. Konservasi eboni (Diospyros celebica Bakh.). Berita Biologi 6(2): 239-243

Tsukaya, H. (2005). Leaf shape: Genetic controls and environmental factors. The International Journal of Developmental Biology. 49, 547-555.

Wulandari, R., Kustiawan, W., Sukartiningsih., Simarangkir, B. D. A. S. (2017). Genetic diversity and kinship of ebony population (Diospyros celebica Bakh.) in its natural population in Central Sulawesi. Journal of Biodiversity and Environmental Sciences (JBES) ISSN: 2220-6663 (Print) 2222-3045 (Online) Vol. 10, No. 6, p. 50-58.

Zhang, P., Wang, H., Wu, Q., Yu, M., Wu, T. (2018). Effect of wind on the relation of leaf N, P stoichiometry with leaf morphology in Quercus species. Forests. 9(3), 110. 


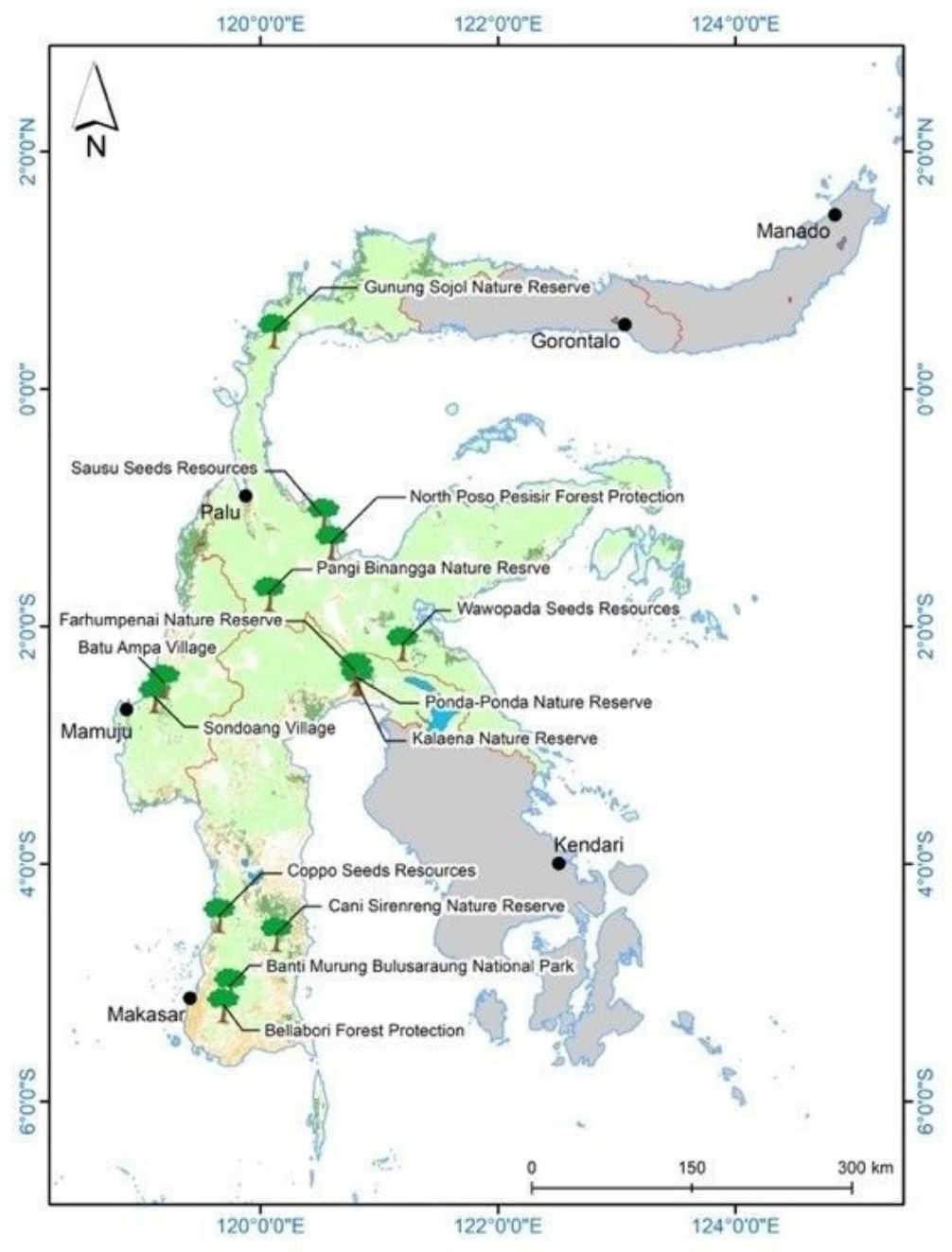

\section{SAMPLING SITE}

LEGEND

- $\quad$ CAPITAL OF THE PROVINCE

- EBONY SAMPLE

PROVINCIAL BOUNDARY

LAKE

PLANTATION

FOREST

SETTLEMENT

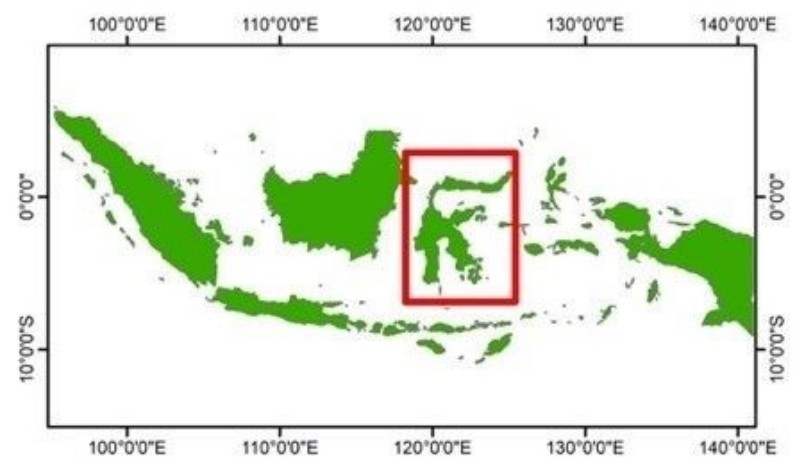

Figure 1

Distribution of 14 sampling locations for Diospyros celebica leaves (Karlinasari et al. 2020) 
A
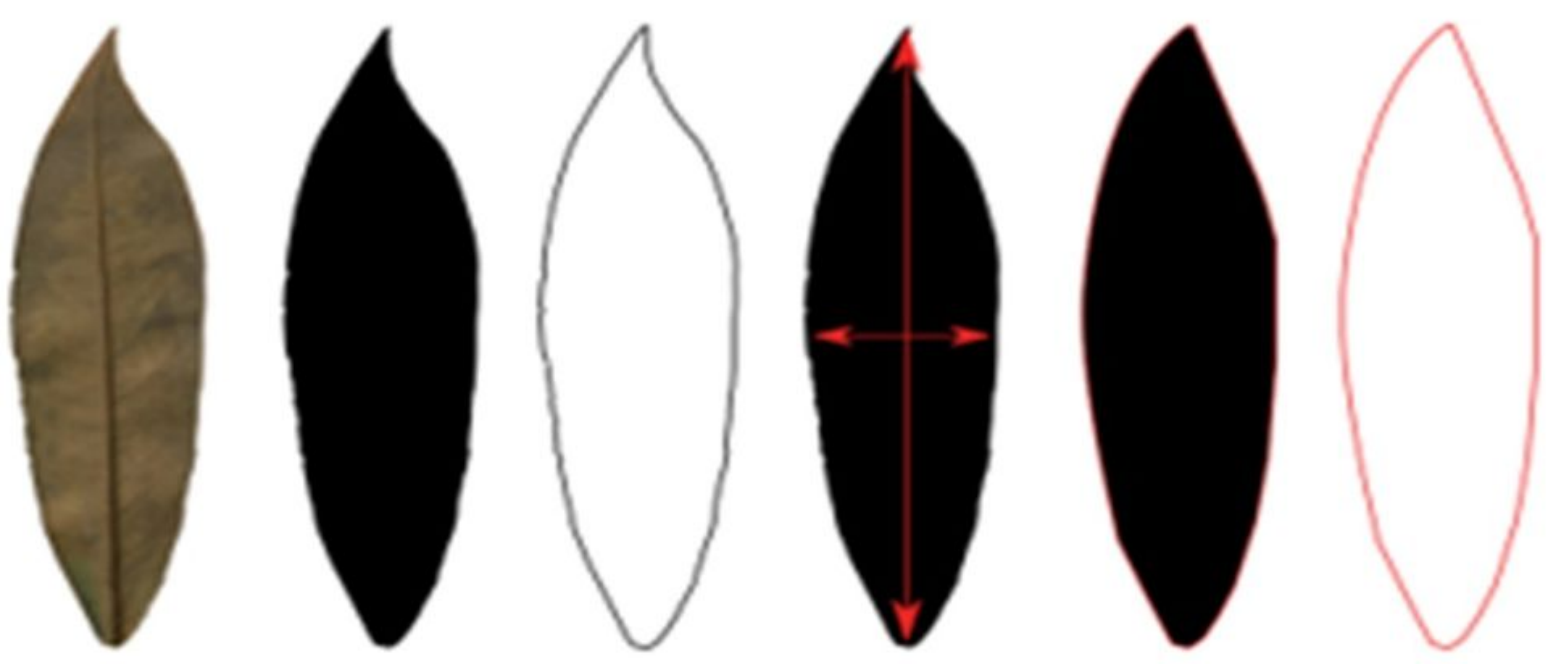

1

3

4

5

6

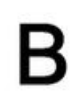

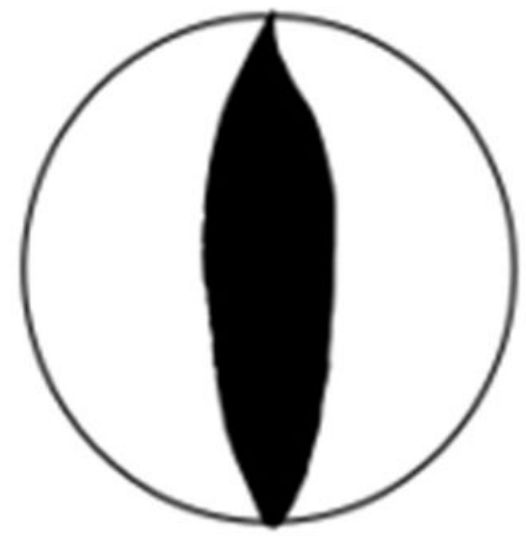

7

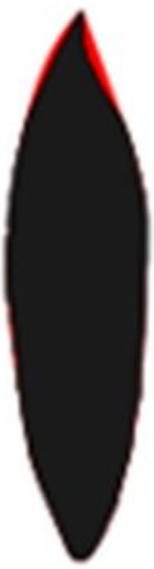

8

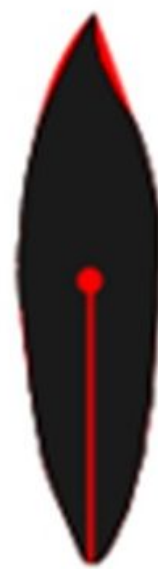

9

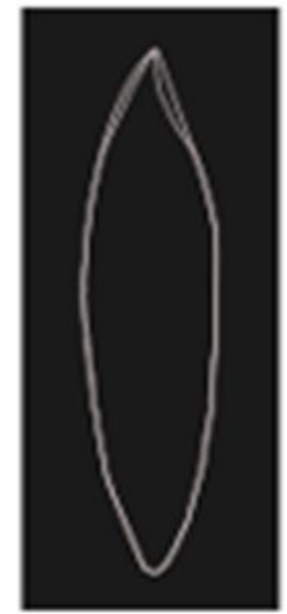

10

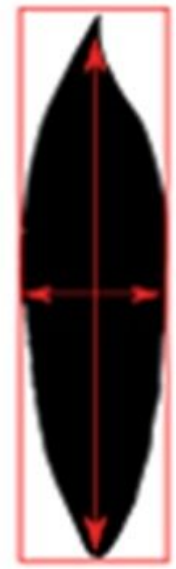

11

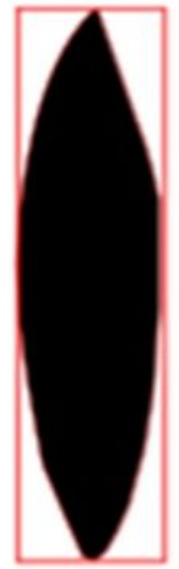

12

\section{Figure 2}

A Main morphological features of Diospyros celebica leaves; (1) original image, (2) area, (3) perimeter, (4) length and width, (5) convex hull area, and (6) convex hull perimeter. B Derivative features of leaf morphology; (7) roundness, (8) solidity, (9) eccentricity, (10) convexity, (11) elongation and (12) rectangularity. 
2 component PCA

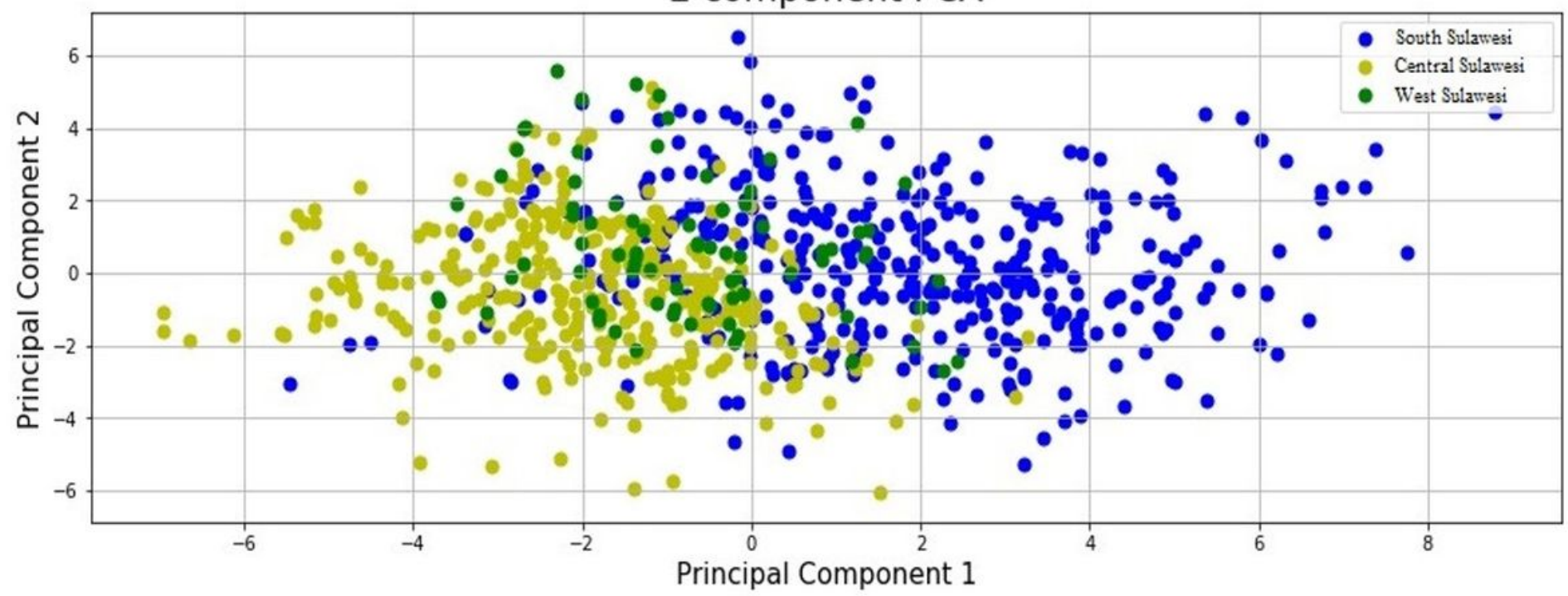

Figure 3

Distribution of leaf data in each province
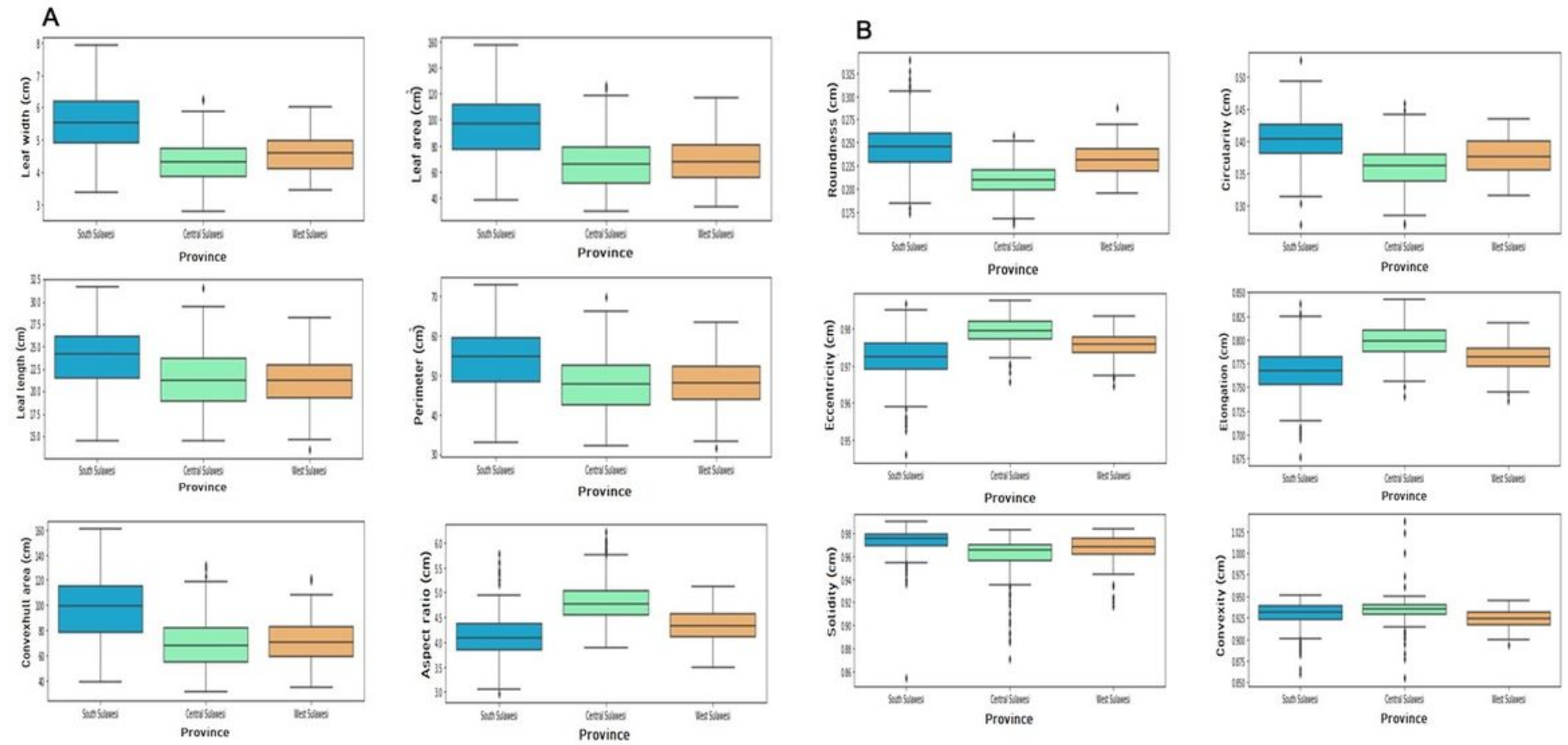

Figure 4

A Boxplot original features of leaf morphology in each province. B Boxplot derivative features of leaf morphology in each province 